\title{
Yeast biotechnology: teaching the old dog new tricks
}

Diethard Mattanovich ${ }^{1,2^{*}}$, Michael Sauer ${ }^{1,2}$ and Brigitte Gasser ${ }^{1,2}$

\begin{abstract}
Yeasts are regarded as the first microorganisms used by humans to process food and alcoholic beverages. The technology developed out of these ancient processes has been the basis for modern industrial biotechnology. Yeast biotechnology has gained great interest again in the last decades. Joining the potentials of genomics, metabolic engineering, systems and synthetic biology enables the production of numerous valuable products of primary and secondary metabolism, technical enzymes and biopharmaceutical proteins. An overview of emerging and established substrates and products of yeast biotechnology is provided and discussed in the light of the recent literature.
\end{abstract}

Keywords: Saccharomyces cerevisiae, Non-conventional yeasts, Metabolic engineering, Biofuels, Recombinant protein, Whole cell biocatalysis

\section{Background}

The use of yeast for food processing and fermentation of alcoholic beverages is traditionally marked as the primary inventive step of biotechnology, dating back several millennia. The discovery of microbial metabolic activities from the 19th century onward initiated the target-oriented development of yeast bioprocesses which were the prototype of modern biotechnological processes. A major hallmark was the development of the "Zulaufverfahren" for efficient baker's yeast production [1]. Today this process is employed under the term "fed-batch" to avoid overflow metabolism in the majority of industrial bioproductions. Efficient fermentative processes developed for ethanol production served as a model for the production of different metabolic products from yeasts, filamentous fungi and bacteria.

Bacteria and filamentous fungi have taken over the lead role in the development of bioprocesses around mid of the 20th century [2]. However since then novel developments of recombinant protein production, metabolic engineering, and systems and synthetic biology, paired by the demand for many products which can be synthesized by yeasts enable a plethora of new applications of yeasts in biotechnology. We see three major fields of

\footnotetext{
* Correspondence: diethard.mattanovich@boku.ac.at

${ }^{1}$ Department of Biotechnology, University of Natural Resources and Life Sciences, Muthgasse 18, 1190 Vienna, Austria

${ }^{2}$ Austrian Centre of Industrial Biotechnology (ACIB GmbH), Vienna, Austria
}

application for yeasts in modern biotechnology: production of metabolites, production of recombinant proteins, and in vivo biotransformations.

Traditionally "yeast" denotes Saccharomyces cerevisiae and its close relatives, used for alcoholic fermentation and baking. However today about 1500 yeast species have been identified (a variable number due to current reclassifications). Biotechnologists have summarized all non-S. cerevisiae yeasts which they use as "non-conventional" yeasts. What unifies them is a lower degree of fermentative overflow metabolism [3] and a rather short history of genetic and biological characterization. The lifestyle of $S$. cerevisiae is characterized by flourishing in extremely high sugar concentrations - disposing most of it as the fermentative by-product ethanol. Most natural habitats however do not provide such extreme substrate conditions so that most non-conventional yeasts provide alternative metabolic routes for substrate utilization and product formation, and different regulatory patterns. A few species of major interest are Pichia pastoris (syn. Komagataella pastoris), Hansenula polymorpha (syn. Ogataea parapolymorpha), Yarrowia lipolytica, Pichia stipitis (syn. Scheffersomyces stipitis), or Kluyveromyces marxianus.

The classical carbon substrates for yeast processes are glucose or sucrose, derived mainly from corn starch and cane sugar. Extrapolating the successful expansion of industrial biotechnology, and most importantly considering 
the food requirements of mankind lets us envisage a shortage of these classical substrates, driving research towards the utilization of alternative carbon sources. Lignocellulose hydrolysate constitutes such an abundant carbon source, requiring yeasts that can utilize xylose and arabinose (the major constituents of hemicellulose). These are either natural pentose assimilating yeasts like e.g. Pichia stipitis [4] or Hansenula polymorpha [5], or S. cerevisiae strains with engineered pentose utilization pathways [6]. Alternatively, glycerol as an abundant by-product of biodiesel production is explored as a substrate for yeast processes. While also $S$. cerevisiae can utilize glycerol, the uptake and assimilation is much higher in other yeasts like Pachysolen tannophilus [7], Y. lipolytica [8,9], or P. pastoris [10].

Different substrates and products of yeast biotechnology are summarized in Figure 1. In the following, the main current applications of yeasts are discussed.

\section{Yeasts as platforms for metabolite production}

Due to the foreseeable limitation of mineral oil resources the interest in biotechnological production of chemicals by microbial metabolic activities is ever increasing. While the first wave of metabolite production processes used natural producers of desired molecules (e.g. production of astaxanthin by Phaffia rhodozyma (syn. Xanthophyllomyces dendrorhous) or production of riboflavin by Pichia guilliermondii), current concepts aim at engineering a few platform strains for the production of many chemicals. Several physiological features predestine yeasts as such a platform [11]: high substrate uptake rates, potentially high metabolic rates, robustness against stressful process conditions. Additionally, there is also a revival in engineering of natural production hosts for improved productivity as the increasing availability of yeast genome sequences enables better understanding and relief of rate-limiting steps based on the results of Omics data and metabolic modelling.

Ethanol made by yeast is by far the largest biotech product [12]. The development of more efficient and robust strains using different substrates has been a major driving force for the development of the yeast platform. However, ethanol as a biofuel suffers from a low substrate yield and a rather low energy content, so that the production of other alcohols like butanol or isobutanol is attempted today [13-16].

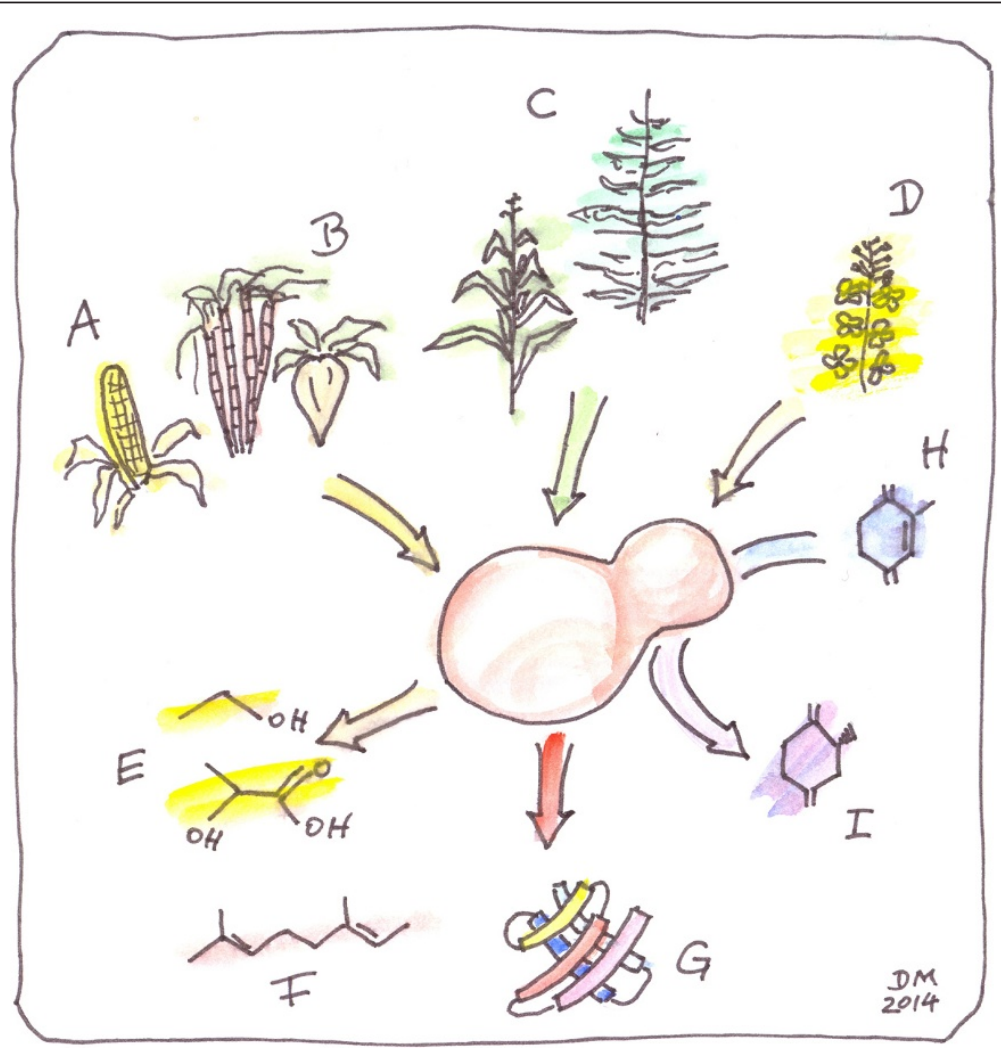

Figure 1 Substrates and products of yeast bioprocesses. Main carbon sources employed in yeast bioprocesses are derived from (A) corn starch, (B) cane or beet sugar, (C) lignocellulose (corn stover, straw, wood etc.) and (D) crude glycerol from biodiesel production. Different native and engineered yeast strains convert the substrate to products of $\mathbf{E}$ ) primary or $\mathbf{( F )}$ secondary metabolism, or $(\mathbf{G})$ recombinant proteins. Whole cell biocatalysis is a special case where $\mathbf{( H )}$ a complex substrate is biochemically transformed to $(\mathbf{I})$ a product by the metabolic activity of yeast cells. Chemical structures are illustrative images only. 
Several short chain organic acids are valued precursor chemicals. Production of the free acid requires low $\mathrm{pH}$ of the culture broth, so that the acid tolerance of yeasts is a valuable feature. Low $\mathrm{pH}$ lactic acid production has been achieved in S. cerevisiae [17], P. stipitis [18], Candida boidinii [19] and Candida sorenensis [20] and is reaching industrial scale. Succinic acid production with engineered $S$. cerevisiae is employed in a process announced to reach $30,000 \mathrm{t} / \mathrm{y}$ scale in 2015 [21].

Efficient pathways for production of phenolic substances such as flavonoids [22] and stilbenoids [23] have been developed but still need further increase of productivity and yield.

Isoprenoids are a universal class of molecules all based on the same building blocks. This universality enables to design novel pathways in yeasts, using the native core structures with specific conversions carried out by heterologous pathways. Thereby, often recombinant genes from different species are combined to obtain the intended variety. Isoprenoids encompass more than 40,000 plant secondary metabolites, a number of them with pharmaceutical activity. Recently yeast based production of the antimalaria agent artemisinin reached commercial production [24]. Isoprenoids produced with recombinant yeast have also been proposed as biobased jet fuel [25].

Polyketides are complex biomolecules mainly of bacterial or fungal origin. Recombinant expression of polyketide synthases in yeasts enables the study of their complex function [26] and the development of heterologous production strains $[27,28]$. The heterologous production of synthetic penicillins in yeasts has been suggested as well [29].

\section{Recombinant protein production in yeasts}

$S$. cerevisiae has been the first yeast employed for production of heterologous proteins [30]. In the early 1980s this was the only yeast species with significant molecular genetic characterization which explains its wide commercial use in the following years for production of human insulin and hepatitis B surface antigen. It has turned out however that other yeasts are more efficient in the production of many recombinant proteins [31-33]. A current literature survey indicates that most work on recombinant protein production in yeasts is performed with $P$. pastoris and $H$. polymorpha, followed by $S$. cerevisiae and $Y$. lipolytica. In 2009, about $20 \%$ of the biopharmaceutical products approved in U.S.A. and Europe were produced in S. cerevisiae [34]. Other yeast platforms play an important role in clinical studies and have begun to enter the biopharma market in the recent years.

Secretion of recombinant proteins to the culture supernatant constitutes a major bottleneck of yeast production hosts [35], favouring some non-conventional yeasts over $S$. cerevisiae [32,33]. A genomic comparison of the secretory pathway of 8 yeast species indicates that $S$. cerevisiae and its close relatives have lost some functions of secretory protein quality control [36]. Engineering of folding and secretion related genes is a valuable strategy to enhance the secretory capacity of yeasts [35,37-39], however the comparison to mammalian cells like Chinese hamster ovary cells shows that there is still a lot of room for improvement [40].

Systems biology has strongly contributed to our current understanding of limitations of protein production [41]. Genome scale transcriptomics and proteomics revealed physiological reactions to protein overproduction [42]. Overexpression has a severe impact on primary metabolism reflecting a higher demand for energy and reducing equivalents $[43,44]$ and free amino acids $[45,46]$. Metabolic engineering may further channel the flux towards required precursers (own unpublished data), and may also contribute to enhanced protein secretion by providing sufficient cofactors, e.g. heme [47].

\section{Whole cell biocatalysis}

To differentiate from microbial metabolite production, whole cell biocatalysis may be defined as the conversion of organic compounds by enzymatic activities of life cells. The main advantages compared to classical biocatalysis are the cheap production of the required enzymatic setup, and/or the use of the cellular metabolism for cofactor regeneration. Recombinant yeast whole cell biocatalysts have been developed for the conversion of cephalosporins [48] and steroids [49], and the asymmetric reduction of $\alpha$-keto esters [50]. Whole cell biocatalysts usually exert their activity intracellularly. However also secreted enzymes may act in in vivo biotransformations. E.g. D-tagatose has been produced from D-lactose by secretory production of bacterial $\beta$-D-galactosidase and L-arabinose isomerase [51]. Yeast surface display of lipase enabled the whole cell based production of phospholipids and fatty acid methyl esters [52].

\section{Conclusions}

Recent research has generated exciting new developments of products and bioprocesses using yeasts. Common patterns of successful yeast based processes are the efficient use of substrate, and a closed energy and redox balance where metabolic engineering may serve to meet the extra demand of product formation. Engineering the protein secretory pathway solves specific problems in overproduction of recombinant proteins.

To provide a forum for scientific discourse, Microbial Cell Factories has initiated a thematic series on Yeast Biotechnology [53]. This virtual series will continue to compile the most relevant papers in yeast research published in Microbial Cell Factories, to serve research in this field for the benefit of mankind. 


\section{Competing interests}

The authors declare that they have no competing interests.

\section{Authors' contributions}

All authors have contributed equally to this commentary, and all have read and approved the final manuscript.

\section{Acknowledgements}

The authors' research on yeast biotechnology is funded by the Federal Ministry of Economy, Family and Youth (BMWFJ), the Federal Ministry of Traffic, Innovation and Technology (bmvit), the Styrian Business Promotion Agency SFG, the Standortagentur Tirol and ZIT - Technology Agency of the City of Vienna through the COMET-Funding Program managed by the Austrian Research Promotion Agency FFG. Additional support by the program "Intelligente Produktion" of FFG, project "Lignoraffinerie" and by the Austrian Science Fund (FWF): Doctoral Program BioToP_Biomolecular Technology of Proteins (FWF W1224) is acknowledged.

Received: 31 December 2013 Accepted: 15 February 2014 Published: 6 March 2014

\section{References}

1. Internatl. Yeast Co. Ltd: Verfahren zur Herstellung von Hefe nach dem Zulaufverfahren. ; 1933. German Patent DE583760.

2. Porro D, Gasser B, Fossati T, Maurer M, Branduardi P, Sauer M, Mattanovich $D$ : Production of recombinant proteins and metabolites in yeasts: when are these systems better than bacterial production systems? Appl Microbiol Biotechnol 2011, 89:939-948.

3. Rozpędowska E, Hellborg L, Ishchuk OP, Orhan F, Galafassi S, Merico A, Woolfit M, Compagno C, Piskur J: Parallel evolution of the makeaccumulate-consume strategy in Saccharomyces and Dekkera yeasts. Nat Commun 2011, 2:302.

4. Toivola A, Yarrow D, van den Bosch E, van Dijken JP, Scheffers WA: Alcoholic fermentation of d-Xylose by yeasts. Appl Environ Microbiol 1984, 47:1221-1223.

5. Ryabova OB, Chmil OM, Sibirny AA: Xylose and cellobiose fermentation to ethanol by the thermotolerant methylotrophic yeast Hansenula polymorpha. FEMS Yeast Res 2003, 4:157-164.

6. Walfridsson M, Hallborn J, Penttilä M, Keränen S, Hahn-Hägerdal B: Xylose-metabolizing Saccharomyces cerevisiae strains overexpressing the TKL1 and TAL1 genes encoding the pentose phosphate pathway enzymes transketolase and transaldolase. Appl Environ Microbiol 1995, 61:4184-4190.

7. Liu X, Mortensen UH, Workman M: Expression and functional studies of genes involved in transport and metabolism of glycerol in Pachysolen tannophilus. Microb Cell Fact 2013, 12:27.

8. Workman M, Holt P, Thykaer J: Comparing cellular performance of Yarrowia lipolytica during growth on glucose and glycerol in submerged cultivations. AMB Express 2013, 3:58.

9. Celińska E, Grajek W: A novel multigene expression construct for modification of glycerol metabolism in Yarrowia lipolytica. Microb Cell Fact 2013, 12:102.

10. Mattanovich D, Graf A, Stadlmann J, Dragosits M, Redl A, Maurer M, Kleinheinz M, Sauer M, Altmann F, Gasser B: Genome, secretome and glucose transport highlight unique features of the protein production host Pichia pastoris. Microb Cell Fact 2009, 8:29.

11. Nielsen J, Larsson C, van Maris A, Pronk J: Metabolic engineering of yeast for production of fuels and chemicals. Curr Opin Biotechnol 2013, 24:398-404.

12. Mussatto SI, Dragone G, Guimarães PM, Silva JP, Carneiro LM, Roberto IC, Vicente A, Domingues L, Teixeira JA: Technological trends, global market, and challenges of bio-ethanol production. Biotechnol Adv 2010, 28:817-830.

13. Steen EJ, Chan R, Prasad N, Myers S, Petzold CJ, Redding A, Ouellet M, Keasling JD: Metabolic engineering of Saccharomyces cerevisiae for the production of n-butanol. Microb Cell Fact 2008, 7:36.

14. Lan El, Liao JC: Microbial synthesis of $n$-butanol, isobutanol, and other higher alcohols from diverse resources. Bioresour Technol 2013, 135:339-349.

15. Branduardi P, Longo V, Berterame NM, Rossi G, Porro D: A novel pathway to produce butanol and isobutanol in Saccharomyces cerevisiae. Biotechnol Biofuels 2013, 6:68.
16. Matsuda F, Ishii J, Kondo T, Ida K, Tezuka H, Kondo A: Increased isobutanol production in Saccharomyces cerevisiae by eliminating competing pathways and resolving cofactor imbalance. Microb Cell Fact 2013, 12:119.

17. Porro D, Bianchi MM, Brambilla L, Menghini R, Bolzani D, Carrera V, Lievense J, Liu CL, Ranzi BM, Frontali L, Alberghina L: Replacement of a metabolic pathway for large-scale production of lactic acid from engineered yeasts. Appl Environ Microbiol 1999, 65:4211-4215.

18. Ilmén M, Koivuranta K, Ruohonen L, Suominen P, Penttilä M: Efficient production of L-lactic acid from xylose by Pichia stipitis. Appl Environ Microbiol 2007, 73:117-123.

19. Osawa F, Fujii T, Nishida T, Tada N, Ohnishi T, Kobayashi O, Komeda T, Yoshida S: Efficient production of L-lactic acid by Crabtree-negative yeast Candida boidinii. Yeast 2009, 26:485-496.

20. Ilmén M, Koivuranta $K$, Ruohonen $L$, Rajgarhia $V$, Suominen $P$, Penttilä M: Production of L-lactic acid by the yeast Candida sonorensis expressing heterologous bacterial and fungal lactate dehydrogenases. Microb Cell Fact 2013, 12:53.

21. Bio-Based News. http://bio-based.eu/news/commercial-production-worldslargest-scale-bio-succinic-acid-plant-2015.

22. Koopman F, Beekwilder J, Crimi B, van Houwelingen A, Hall RD, Bosch D, van Maris AJ, Pronk JT, Daran JM: De novo production of the flavonoid naringenin in engineered Saccharomyces cerevisiae. Microb Cell Fact 2012, 11:155.

23. Wang $Y$, Halls C, Zhang J, Matsuno M, Zhang Y, Yu O: Stepwise increase of resveratrol biosynthesis in yeast Saccharomyces cerevisiae by metabolic engineering. Metab Eng 2011, 13:455-463.

24. Paddon CJ, Westfall PJ, Pitera DJ, Benjamin K, Fisher K, McPhee D, Leavell MD, Tai A, Main A, Eng D, Polichuk DR, Teoh KH, Reed DW, Treynor T, Lenihan J, Fleck M, Bajad S, Dang G, Dengrove D, Diola D, Dorin G, Ellens KW, Fickes S, Galazzo J, Gaucher SP, Geistlinger T, Henry R, Hepp M, Horning $T$, lqbal $T$, Jiang $H$, Kizer L, Lieu B, Melis D, Moss N, Regentin R, Secrest S, Tsuruta H, Vazquez R, Westblade LF, Xu L, Yu M, Zhang Y, Zhao L, Lievense J, Covello PS, Keasling JD, Reiling KK, Renninger NS, Newman JD: High-level semi-synthetic production of the potent antimalarial artemisinin. Nature 2013, 496:528-532

25. Peralta-Yahya PP, Ouellet M, Chan R, Mukhopadhyay A, Keasling JD, Lee TS: Identification and microbial production of a terpene-based advanced biofuel. Nat Commun 2011, 2:483.

26. Ishiuchi K, Nakazawa T, Ookuma T, Sugimoto S, Sato M, Tsunematsu Y, Ishikawa N, Noguchi H, Hotta K, Moriya H, Watanabe K: Establishing a new methodology for genome mining and biosynthesis of polyketides and peptides through yeast molecular genetics. Chembiochem 2012, 13:846-854.

27. Gao L, Cai M, Shen W, Xiao S, Zhou X, Zhang Y: Engineered fungal polyketide biosynthesis in Pichia pastoris: a potential excellent host for polyketide production. Microb Cell Fact 2013, 12:77.

28. Rugbjerg P, Naesby M, Mortensen UH, Frandsen RJ: Reconstruction of the biosynthetic pathway for the core fungal polyketide scaffold rubrofusarin in Saccharomyces cerevisiae. Microb Cell Fact 2013, 12:31.

29. Gidijala L, Kiel JA, Douma RD, Seifar RM, van Gulik WM, Bovenberg RA, Veenhuis $M$, van der Klei IJ: An engineered yeast efficiently secreting penicillin. PLoS One 2009, 4:e8317.

30. Hitzeman RA, Hagie FE, Levine HL, Goeddel DV, Ammerer G, Hall BD: Expression of a human gene for interferon in yeast. Nature 1981, 293:717-722.

31. Mattanovich D, Branduardi P, Dato L, Gasser B, Sauer M, Porro D: Recombinant protein production in yeasts. Methods Mol Biol 2012, 824:329-358.

32. Dragosits $M$, Frascotti G, Bernard-Granger L, Vázquez F, Giuliani M, Baumann K, Rodríguez-Carmona E, Tokkanen J, Parrilli E, Wiebe MG, Kunert R, Maurer M, Gasser B, Sauer M, Branduardi P, Pakula T, Saloheimo M, Penttilä M, Ferrer P, Luisa Tutino M, Villaverde A, Porro D, Mattanovich D: Influence of growth temperature on the production of antibody Fab fragments in different microbes: a host comparative analysis. Biotechnol Prog. 2011, 27:38-46.

33. Mack M, Wannemacher M, Hobl B, Pietschmann P, Hock B: Comparison of two expression platforms in respect to protein yield and quality: Pichia pastoris versus Pichia angusta. Protein Expr Purif 2009, 66:165-171.

34. Ferrer-Miralles N, Domingo-Espín J, Corchero JL, Vázquez E, Villaverde A: Microbial factories for recombinant pharmaceuticals. Microb Cell Fact 2009, 8:17.

35. Delic M, Göngrich R, Mattanovich D, Gasser B: Engineering of protein folding and secretion - strategies to overcome bottlenecks for efficient production of recombinant proteins. Antioxid Redox Signal 2014. [Epub ahead of print] doi:10.1089/ars.2014.5844. 
36. Delic M, Valli M, Graf AB, Pfeffer M, Mattanovich D, Gasser B: The secretory pathway: exploring yeast diversity. FEMS Microbiol Rev 2013, 37:872-914.

37. Idiris A, Tohda $H$, Kumagai $H$, Takegawa $K$ : Engineering of protein secretion in yeast: strategies and impact on protein production. Appl Microbiol Biotechnol 2010, 86:403-17.

38. Damasceno LM, Huang CJ, Batt CA: Protein secretion in Pichia pastoris and advances in protein production. Appl Microbiol Biotechnol 2012, 93:31-9.

39. Hou J, Tyo KE, Liu Z, Petranovic D, Nielsen J: Metabolic engineering of recombinant protein secretion by Saccharomyces cerevisiae. FEMS Yeast Res 2012, 12:491-510.

40. Maccani A, Landes N, Stadlmayr G, Maresch D, Leitner C, Maurer M, Gasser B, Ernst W, Kunert R, Mattanovich D: Pichia pastoris secretes recombinant proteins less efficiently than Chinese hamster ovary cells but allows higher space-time yields for less complex proteins. Biotechnol I 2014. [Epub ahead of print] doi: 10.1002/biot.201300305.

41. Graf A, Dragosits M, Gasser B, Mattanovich D: Yeast systems biotechnology for the production of heterologous proteins. FEMS Yeast Res 2009, 9:335-48.

42. Vanz AL, Lünsdorf H, Adnan A, Nimtz M, Gurramkonda C, Khanna N, Rinas U: Physiological response of Pichia pastoris GS115 to methanol-induced high level production of the Hepatitis B surface antigen: catabolic adaptation, stress responses, and autophagic processes. Microb Cell Fact 2012, 11:103

43. Jordà J, Jouhten P, Cámara E, Maaheimo H, Albiol J, Ferrer P: Metabolic flux profiling of recombinant protein secreting Pichia pastoris growing on glucose:methanol mixtures. Microb Cell Fact 2012, 11:57.

44. Klein T, Lange S, Wilhelm N, Bureik M, Yang TH, Heinzle E, Schneider K: Overcoming the metabolic burden of protein secretion in Schizosaccharomyces pombe - A quantitative approach using (13)C-based metabolic flux analysis. Metab Eng 2014, 21:34-45.

45. Carnicer M, Ten Pierick A, van Dam J, Heijnen JJ, Albiol J, van Gulik W, Ferrer P: Quantitative metabolomics analysis of amino acid metabolism in recombinant Pichia pastoris under different oxygen availability conditions. Microb Cell Fact 2012, 11:83.

46. Heyland J, Fu J, Blank LM, Schmid A: Carbon metabolism limits recombinant protein production in Pichia pastoris. Biotechnol Bioeng 2011, 108:1942-53.

47. Liu L, Martínez JL, Liu Z, Petranovic D, Nielsen J: Balanced globin protein expression and heme biosynthesis improve production of human hemoglobin in Saccharomyces cerevisiae. Metab Eng 2014, 21:9-16.

48. Abad S, Nahalka J, Bergler G, Arnold SA, Speight R, Fotheringham I, Nidetzky B, Glieder A: Stepwise engineering of a Pichia pastoris D-amino acid oxidase whole cell catalyst. Microb Cell Fact 2010, 9:24.

49. Braun A, Geier M, Bühler B, Schmid A, Mauersberger S, Glieder A: Steroid biotransformations in biphasic systems with Yarrowia lipolytica expressing human liver cytochrome P450 genes. Microb Cell Fact 2012, 11:106.

50. Kratzer R, Egger S, Nidetzky B: Integration of enzyme, strain and reaction engineering to overcome limitations of baker's yeast in the asymmetric reduction of alpha-keto esters. Biotechnol Bioeng 2008, 101:1094-101.

51. Wanarska M, Kur J: A method for the production of D-tagatose using a recombinant Pichia pastoris strain secreting $\beta$-D-galactosidase from Arthrobacter chlorophenolicus and a recombinant L-arabinose isomerase from Arthrobacter sp. 22c. Microb Cell Fact 2012, 11:113.

52. Hama S, Yoshida A, Nakashima K, Noda H, Fukuda H, Kondo A: Surfactantmodified yeast whole-cell biocatalyst displaying lipase on cell surface for enzymatic production of structured lipids in organic media. App/ Microbiol Biotechnol 2010, 87:537-43.

53. Yeast biotechnology. www.microbialcellfactories.com/series/Yeast Biotechnology.

doi:10.1186/1475-2859-13-34

Cite this article as: Mattanovich et al:: Yeast biotechnology: teaching the old dog new tricks. Microbial Cell Factories 2014 13:34.

\section{Submit your next manuscript to BioMed Central and take full advantage of:}

- Convenient online submission

- Thorough peer review

- No space constraints or color figure charges

- Immediate publication on acceptance

- Inclusion in PubMed, CAS, Scopus and Google Scholar

- Research which is freely available for redistribution

Submit your manuscript at www.biomedcentral.com/submit
Ciomed Central 